\title{
Aktivitas Anti UV-B Ekstrak Fenolik dari Tongkol Jagung (Zea mays L.)
}

\author{
Liemey I. Lumempouwa* ${ }^{*}$ Edi Suryantoa, Jessy J.E. Paendonga \\ aJurusan Kimia, FMIPA, Unsrat, Manado
}

K A T A K U N C I

Tongkol Jagung

Fenolik

SPF

\begin{tabular}{l}
$\overline{\text { K E Y W O R D S }}$ \\
\hline Corn Cobs \\
Phenolic \\
SPF
\end{tabular}

A B S T R A K
Tujuan penelitian ini adalah untuk menentukan kandungan total
fenolik dari ekstrak tongkol jagung dan aktivitasnya sebagai anti UV-B.
Tongkol jagung diekstrak dengan pelarut etanol 20 (E20), 40 (E40), 60
(E60) dan $80 \%$ (E80) dengan cara refluks. Setelah itu, ekstrak dianalisis
kandungan total fenolik dengan metode Folin-Ciocalteu. Hasil penelitian
menunjukkan bahwa ekstrak tongkol jagung E20, E40, E60 dan E80
mengandung total fenolik berturut-turut adalah 38,98; 56,02; 66,84 dan
73,06 mg/kg. Hasil menunjukkan bahwa ekstrak tongkol jagung memiliki
kandungan senyawa fenolik yang dapat berpotensi sebagai bahan aktif
tabir surya.
A B S T R A T
The aims of this study was to determine the total phenolic
compounds and the anti-UV-B activity of the corn cob extracts. The
samples of the corn cobs were reflux-extracted with ethanol 20 (E20), 40
(E40), 60 (E60) and $80 \%$ (E80). The total phenolic compounds of the
extracts were then analyzed usng Folin-Ciocalteu method. The result
showed that the total phenolic compounds of the corn cobs extracts E20,
E40, E60 and E80 were 38.98; 56.02; 66.84 and 73.06 mg/kg
respectively. The results also showed that corn cobs extracts contained
phenolic compounds that have the potential as sunscreen active
ingredients.

\section{Pendahuluan \\ Tongkol jagung merupakan bagian terbesar dari limbah jagung. Dari berat jagung bertongkol, diperkirakan 40-50\% adalah tongkol jagung, yang besarnya dipengaruhi oleh varietas jagungnya. Oleh karena itu dapat diperkirakan untuk produksi jagung 13 juta ton (jagung pipilan) akan terjadi limbah tongkol jagung sekitar 10,6 juta ton/tahun (Richana, et al., 2004). Berdasarkan hal tersebut perlu adanya perhatian dan penanganan untuk pemanfaatan limbah tongkol jagung sehingga dapat lebih bermanfaat. Selama ini limbah tongkol jagung hanya dibuang, atau hanya digunakan sebagai bahan bakar dapur dan pengasapan untuk mengusir nyamuk.}

Sinar matahari merupakan sumber energi yang berperan penting bagi kehidupan makhluk di bumi yang terbagi atas berbagai jenis, diantaranya sinar ultraviolet (UV) A, B, dan C. Namun, di samping efek yang menguntungkan, paparan sinar matahari yang melimpah dengan intensitas yang tinggi dapat menyebabkan hiperpigmentasi kulit sehingga kulit menjadi kusam dan bersisik bahkan dapat meningkatkan risiko kanker kulit. Efek tersebut terutama disebabkan oleh sinar UV A dan B.

Kaur dan Saraf (2009) mengemukakan bahwa dalam jumlah kecil, radiasi UV-B bermanfaat untuk sintesis vitamin D dalam tubuh, tetapi paparan berlebihan sinar ini dapat menyebabkan kulit kemerahan/terbakar dan efek berbahaya sintesis radikal bebas yang memicu eritema dan katarak. Sinar UV-B juga dapat menyebabkan kerusakan fotokimia pada DNA sel sehingga memicu pertumbuhan kanker kulit. Beberapa upaya umum yang dilakukan untuk mencegah timbulnya berbagai penyakit pada kulit akibat paparan sinar UV antara lain melalui penggunaan tabir surya (sunscreen), yang biasanya berupa salep atau krim yang mengandung bahan kimia yang dapat melindungi kulit.Pada tahuntahun belakangan ini, terdapat beberapa senyawa bahan alam yang telah dimanfaatkan sebagai agen pelindung sinar UV. Misalnya, Vitamin C, E dan B-

*Corresponding author: Jurusan Kimia FMIPA UNSRAT, Jl. Kampus Unsrat, Manado, Indonesia 95115; Email address: liemeyivi@yahoo.com Published by FMIPA UNSRAT (2012) 
karoten yang digunakan dalam produk perawatan kulit. Selain itu,penelitian Svobodova et al. (2003) menunjukkan bahwa senyawa-senyawa fenolik dapat berperan sebagai bahan aktif tabir surya.

Tongkol jagung merupakan simpanan makanan untuk pertumbuhan biji jagung selama melekat pada tongkol, oleh sebab itu tongkol jagung diduga memiliki senyawa-senyawa aktif yang dapat berpotensi sebagai bahan aktif tabir surya. Telah diteliti sebelumnya tentang jagung, oleh Hossain et al. (2006) dengan mengidentifikasi senyawa antioksidan flavonol glikosida dan kuersetin dari biji jagung, dan Mongan et al. (2011) mengenai antioksidan asap cair yang dibuat dari bahan dasar tongkol jagung. Penelitian ini bertujuan untuk menentukan kandungan total fenolik dari ekstrak tongkol jagung dan aktivitasnya sebagai anti UV-B.

\section{Metode}

\subsection{Bahan dan Alat}

Bahan-bahan yang digunakan dalam penelitian ini adalah tongkol jagung. Bahan kimia yang digunakan adalah etanol, larutan natrium karbonat $\left(\mathrm{Na}_{2} \mathrm{CO}_{3}\right) 2 \%$, reagen Folin-Ciocalteu 50\%. Peralatan yang digunakan dalam penelitian ini adalah alat-alat gelas Pyrex, erlenmeyer, botol kaca transparan, mikropipet, blender, alat refluks (pemanas listrik, labu kaca, kondensor), vortex, neraca elektrik ER-180 a, rotary evaporator Eyela N-1000, spektrofotometer Milton Roy. Sedangkan alat yang digunakan untuk manganalisa nilai SPF yaitu spektrofotometer UV-Vis Shimadzu Pharma 1700.

\subsection{Persiapan sampel}

Sampel yang digunakan adalah tongkol jagung kering jenis hibrida yang berasal dari Gorontalo. Tongkol jagung dipotong-potong kecil dan dihancurkan dengan blender.

\subsection{Ekstraksi}

Tongkol jagung diekstraksi menggunakan pelarut etanol 20, 40, 60, dan 80\% (E20, E40, E40 dan E80). Ekstraksi dilakukan secara refluks. Sebanyak $25 \mathrm{~g}$ tongkol jagung dimasukkan dalam labu distilat, ditambahkan pelarut etanol $250 \mathrm{~mL}$ hingga sampel terendam semuanya, lalu dipanaskan selama 2 jam pada suhu $78-90^{\circ} \mathrm{C}$. Filtrat disaring lalu diuapkan untuk menghilangkan pelarutnya dengan menggunakan rotary evaporator, lalu dioven sampai kering sehingga diperoleh ekstrak tongkol jagung.

\subsection{Analisis kandungan fenolik dan nilai SPF}

Analisis kandungan fenolik dilakukan dengan menggunakan metode Folin-Ciocalteu (Conde et al., 1997). Absorbansinya dibaca pada $\lambda 750 \mathrm{~nm}$ dengan spektrofotometer. Penentuan efektivitas tabir surya dilakukan dengan menentukan nilai SPF secara in vitro dengan metode spektrofotometri (Sayre et al., 1979). Nilai SPF ditentukan dengan rumus (SPF $=\mathrm{CF}$ x $\sum_{290}^{320} E E(\lambda) \times \mathrm{I}(\lambda) \times$ absorbansi $\left.(\lambda)\right)$ dimana $C F=$ Faktor Koreksi (10), EE= Efisiensi Eritermal, I = Spektrum Simulasi sinar Surya

\section{Hasil dan Pembahasan}

Rendemen dari hasil ekstraksi $25 \mathrm{~g}$ tongkol jagung menggunakan pelarut etanol sebanyak 250 $\mathrm{mL}$ dengan empat macam konsentrasi dapat dilihat pada Tabel 1.

Tabel 1 - Hasil ekstrak pekat tongkol jagung.

\begin{tabular}{|c|c|c|c|}
\hline Ekstrak & Rendemen(\%) & Warna & Total fenolik(mg/kg) \\
\hline E20 & 1.56 & Coklat Tua & 38,98 \\
E40 & 2.19 & Coklat & 56,02 \\
E60 & 2.49 & Coklat & 66,84 \\
E80 & 1.77 & Coklat Muda & 73,06 \\
\hline
\end{tabular}

Pada Tabel 1, rendemen tertinggi ada pada ekstrak E60 dan E40, hal ini dikarenakan kandungan senyawa fenolik memiliki cincin aromatik yang berikatan dengan gugus hidroksil, yang relatif dapat mengurangi sifat kepolaran dari senyawa fenolik sehingga lebih suka larut pada pelarut polar seperti etanol yang berkonsentrasi tinggi.

Hasil ekstraksi tongkol jagung dari empat macam konsentrasi pelarut (E20, E40, E60 dan E80) dibuat dengan konsentrasi $1000 \mathrm{\mu g} / \mathrm{mL}$ kemudian diuji kandungan total Fenolik. Hasil analisis kandungan total fenolik, yang diperoleh di sajikan pada Gambar 1.
Berdasarkan Gambar 1 diketahui bahwa ekstrak tongkol E80 memiliki kandungan total fenol yang paling tinggi yaitu $73,06 \mathrm{mg} / \mathrm{kg}$, ini disebabkan senyawa fenol mencakup sejumlah senyawa-senyawa yang umumnya mempunyai sebuah cincin aromatik dengan satu atau lebih gugus hidroksil (Geisman dan Crout, 1969).Cincin aromatik membuat senyawa ini berkurang kepolarannya sehingga sifat konsentrasi etanol yang tinggi lebih mampu melarutkan senyawa fenolik karena etanol selain bersifat polar juga memiliki gugus non polar yaitu $\mathrm{CH}_{3}-\mathrm{CH}_{2^{-}}$yang membuat senyawa fenolik lebih suka larut dalam pelarut etanol. Gambar 1 menunjukkan dengan jelas bahwa semakin rendah konsentrasi etanol sebagai 
pelarut, semakin rendah pula kandungan senyawa fenolik yang terdapat dalam ekstrak tongkol jagung.

Alkohol merupakan pelarut serbaguna yang sangat baik untuk ekstraksi karena dapat mengekstraksi senyawa polar dan nonpolar. Penggunaan air sebagai larutan pengekstrak juga disebabkan oleh air dapat mengekstraksi senyawasenyawa yang bersifat polar karena air bersifat polar, sedangkan etanol mempunyai dua gugus yang berbeda kepolarannya, yaitu gugus hidroksil yang bersifat polar dan gugus alkil yang bersifat nonpolar.

Adanya kedua gugus tersebut pada etanol diharapkan senyawa-senyawa dengan tingkat kepolaran yang berbeda akan terekstrak dalam etanol (Harborne, 1987).

\subsection{Penentuan nilai SPF secara in vitro}

Penentuan efektivitas anti UV-B dilakukan dengan penentuan nilai SPF secra in vitro menggunakan spektrofotometer UV/Vis pada panjang gelombang 290 sampai $320 \mathrm{~nm}$ (sesuai panjang gelombang UV-B). Nilai SPF dari ekstrak tongkol jagung dengan keempat macam konsentrasi pelarutnya dan nilai SPF kontrol positif disajikan pada Tabel 2.

Tabel 2 memperlihatkan bahwa nilai SPF yang didapatkan sejalan dengan hasil kandungan total fenolik yang terkandung dalam masing-masing ekstrak. Hal ini dapat dilihat dari semakin tinggi kandungan total fenolik dalam ekstrak semakin tinggi juga nilai SPF atau daya proteksi terhadap sinar UV-B.

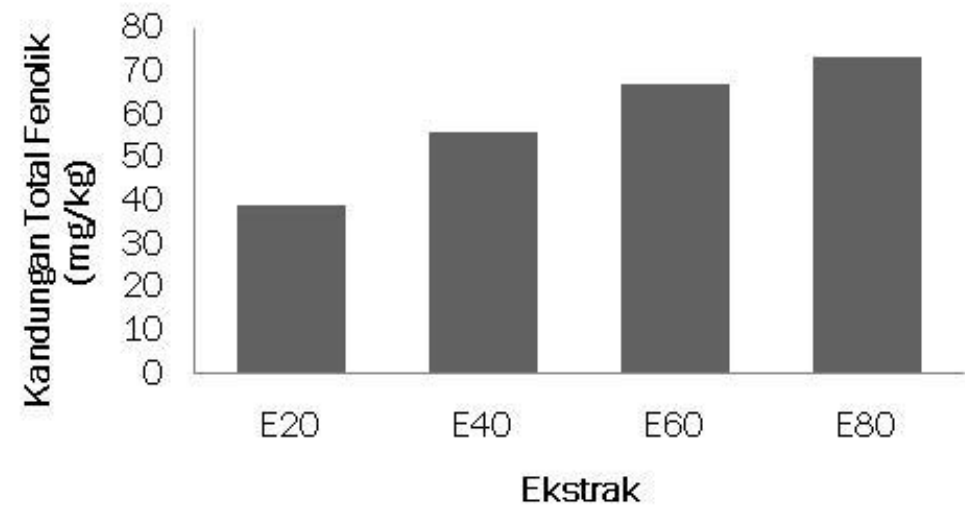

Gambar 1 - Grafik total kandungan fenolik dari tongkol jagung. Singkatan dalam gambar ini sesuai dengan Tabel 1.

Tabel 2 - Perbandingan nilai SPF dari ekstrak tongkol jagung dengan empat macam konsentrasi.

\begin{tabular}{|c|c|c|c|c|}
\hline \multirow{2}{*}{$\begin{array}{c}\text { Konsentrasi } \\
(\mu \mathrm{g} / \mathrm{mL})\end{array}$} & $\mathrm{4}$ Nilai SPF \\
\cline { 2 - 5 } & & $\mathrm{E} 40$ & $\mathrm{E} 60$ & $\mathrm{E} 80$ \\
\hline & 1,99 & 2,96 & 4,08 & 7,52 \\
100 & 4,98 & 7,33 & 8,17 & 12,24 \\
150 & 7,64 & 11,90 & 12,89 & 15,81 \\
200 & 10,37 & 13,89 & 15,57 & 17,78 \\
\hline \multicolumn{5}{|c|}{ Singkatan dalam tabel ini sesuai dengan Tabel 1. } \\
\hline
\end{tabular}

Ekstrak dengan pelarut etanol $80 \%$ memiliki nilai SPF tertinggi yaitu 17,78 pada konsentrasi 200 $\mu \mathrm{g} / \mathrm{mL}$, ini menunjukkan kemampuan ekstrak tersebut berperan sebagai tabir surya. Seiring bertambahnya konsentrasi, maka daya proteksi terhadap sinar matahari khususnya UV-B juga semakin tinggi. Menurut Bonina (2005), Kandungan senyawa fenolik terbukti mampu melindungi kulit dari kerusakan akibat efek induksi dari radiasi UV.

\section{Kesimpulan}

Penelitian ini menyimpulkan bahwa ekstrak tongkol jagung memiliki kandungan fenolik. Ekstrak E80 menunjukkan kandungan fenolik tertinggi diikuti dengan ekstrak E60, E40 dan E20. Ekstrak E80 memiliki kemampuan sebagai bahan aktif tabir surya yang paling baik, dengan nilai SPF lebih tinggi daripada ekstrak E60, E40 dan E20. Ini menunjukan bahwa kandungan fenolik yang tinggi meningkatkan nilai SPF.

\section{Daftar Pustaka}

Bonina, F; Lanza, M; Lucia, M; Claudio, P; Antonio, T; Domenico, T; Castelli, F; Saija, A. Flavonoid as potential Protective Agents Against Photo-oxidative Skin Damage. Int. J. of Pharm. 2005, 146, 87-94. 
Conde, E.E; Cadahia, M.C; Vallejo, G; Simon, B.F.D; Adradors, J.R.G. Low Molecular Weight Polyphenol In Cork of Querceus Suber. J. Agric. Food Chem. 1997, 45, 2695-2700.

Geisman TA dan DHG. Crout. Organic Chemistry of Secondary Plant . Metabolisme; Freeman Cooper and Co: California, 1969.

Harborne, J.B. Metode Fitokimia, Penuntun Cara Modern Menganalisis Tumbuhan. Terjemahan K. Padmawinata dan I Soediro: ITB: Bandung, 1987.

Hossain, A. M.; Islam, A; Jolly, Y. N; Kabir, M. J. A. New Flavonol Glycoside from the Seeds of Zea Mays $L$. Indian J. Chem. 2006, 45, 1319-1321.

Kaur, C. D dan S. Saraf. In Vitro Sun Protection Factor Determination of Herbal Oils Used in Cosmetics. Pharmacogn. Res. 2009, 2, 22-23.
Mongan, J; Suryanto, E; Rumengan, I. Produksi Fraksinasi Asap Cair dari Limbah Tongkol Jagung untuk Penghambatan Peroksidasi Lipida Ikan Layang. Chem. Prog.. 2011, 4, 34-44.

Richana, N; Lestina, P; Irawadi, T. T. Karakterisasi Lignoselulosa: Xylan dari Limbah Tanaman Pangan dan Pemanfaatannya untuk Pertumbuhan Bakteri RXA III-5 penghasil xilanase. J. Penelitian Pertanian. 2004, 23, 171-176.

Sayre, R. M., Agin, P.P., Levee, G.J., Marlowe, E. A Comparison of In Vivo and In Vitro Testing On Sunscreening Formulas. Photochem. Photobiol. 1979, 29, 559-566.

Svobodova, A; Psotova, J; Walterova, D. Natural Phenolics in the Prevention of UV-Induced Skin Damage. Biomed. Pap. 2003, 147, 137-145. 